generations, both because the price of the vaceine has fallen, and because polio vaccine will be integrated with other immunization programmes. The report estimates that the immunization campaign has already savod 1,600 people from permanent paralysis. However, there are still between 7,500 and 10,000 victims of earlier epidemics suffering from some degree of paralysis. There is a danger that their plight may be forgotten now that polio has been so nearly eradicated. The Office of Health Economics in conjunction with the British Polio Fellowship is at present undertaking the first survey carried out among polio victims (The Price of Poliomyelitis. Pp. 35. London: Office of Health Economics, 1963. 2s.).

\section{Designing Suitable Work for the Disabled}

If all the 660,000 registered disabled persons in Britain were used efficiently and productively the effective labour force would be inereased signifieantly. Ergonomies offers a special approach to this problem and is lucidly described in Dr. W. Griew's booklet Design for Work for the Disabled (Ergonomics for Industry, 3. Pp. 12. By Dr. Stephen Griew. London: Department of Scientific and Industrial Research, 1963). Dr. Griew distinguishes between a disability in the medical sense and a handicap in the occupational. For a handicapped worker two obvious solutions, applying ergonomic principles, are suggested. The first is simply to find a job within the worker's limited capacities; the second to fit the job to the handicapped person. In the case of the disabled worker he discusses the problems involved where there is limited movement of lower or upper limbs, or when the ability to bend, stoop, lift or carry is affected. He deals separately with the interrelated questions of noise, visual work, dust and fumes. Dr. Griew also assesses responsibility. If the important principles he describes are to be adopted widely, the personnel officer, the factory doctor, the production engineer, the work-study engineer and the designer all need to be consulted.

\section{Fulbright Travel Grants}

UNDER the provisions of the Fulbright programme, travel grants are available to citizens of the United Kingdom and dependent territories to go to the United States of America for academic or educational purposes, provided that they have adequate financial support in dollars for the proposed period of the visit to the United States, and can show proof of admission to an institution of higher learning in the United States for a minimum poriod of nine months. All grants cover the cost of direct round-trip travel between a candidate's home and the American university or institution. They are available betwoen June 1 and August 15, 1964, for which applica. tion must be received by March 16, 1964, and between August 16, 1964, and April 1, 1965, for which applications must be received by June 1, 1964. Application forms and further information can be obtained from the United States Educational Commission in the United Kingdom, 71 South Audley Street, London, W.1.

\section{University News :}

London

The Calendar 1963-64 of University College, London, now available, contains a brief history of the College as well as the usual information regarding officers, staff, courses, awards, library, ete. (Pp. Ixxxiii + 482. London: University College, 1963). There is also a list of publications obtainable, such as inaugural lectures and the Chambers Memorial Lectures. Students in 1962-63 numbered 2,816 men (916 postgraduate) and 1,124 women (216 postgraduate), and of this total 397 men and 293 women were part-time.

Sheffield

THE following appointments have been announced: Dr.R.Mason, formerly lecturer in chemistry in the Imperial
College of Science and Technology, London, to the chair of inorganic chemistry. Senior Lecturer, Dr. J. R. Quayle (biochemistry). Lecturers, Dr. E. J. Clegg (human biology and anatomy); Dr. J. B. Davies (electrical engineering); Mr. I. Pilowsky (chemistry); Dr. R. W. Teale (physics).

\section{Announcements}

Dr. J. G. Ramsay, Department of Geology, Imperial College of Science and Technology, London, has been awarded the Clough Award for 1963 by the Edinburgh Geological Society, in recognition of his outstanding and meritorious work on the strueture and stratigraphy of the Moine rocks of Scotland. The Award will be presented at the annual general meeting of the Society on November 20.

THE sixteenth technical exhibition of the Oil and Colour Chemists' Association will be held at the Old and New Halls of the Royal Horticultural Society, Westminster, London, S.W.1, during March 16-19, 1964. Further information can be obtained from R. H. Hamblin, Wax Chandlers' Hall, Gresham Street, London, E.C.2.

A symposium on "Hair" in all its aspects will be held, under the auspices of the Society of Cosmetic Chemists of Great Britain, at Brighton, Sussex, during April 14-16, 1964. Anyone wishing to present a paper is requested to contact the honorary organizer, Mr. R. E. Eckton, Givaudan and Co., Ltd., Godstone Road, Whyteleafe, Surrey.

THe first international symposium on "Radiosensitizers and Radioprotective Drugs", arranged by the European Society for Biochemical Pharmacology, will be held in Milan during May 23-24. The programme will include sessions on: immediate and long-distance effects of ionizing radiations; drugs interfering with radiation effects; clinical investigations with radiosensitizers and radioprotective drugs. Further information can be obtained from Prof. R. Paoletti, Institute of Pharmacology, University of Milan, Via A. del Sarto 21, Milan.

The fifteenth conference on "Analytical Chemistry and Applied Spectroscopy" will bo held at the Penn-Sheraton Hotel in Pittsburgh, Pennsylvania, during March 2-6, 1964. Approximately 200 papers on all phases of analytical chemistry and spectroscopy will be presented. Symposia on the following subjects are proposed for the 1964 conference: (1) Coblentz Society Symposium; (2) excitation techniques; (3) electron probe; (4) analysis of polymers; (5) analysis of gases in metal including activation methods; (6) far infra-red; (7) adsorb molecules. Further information can be obtained from $\mathrm{Mr}$. Rudolph B. Fricioni, Allegheny Ludlum Steel Corporation, Corporate Quality Control Laboratory, Research Conter, Brackenridge, Pennsylvania.

A CONFERENCE on "The Electrical and Magnetic Properties of Thin Films in Relation to their Structure", arranged jointly by the Electronics, Electron Microseopy and Analysis and Low Temperature Groups of the Institute of Physics and the Physical Society, will be held at the Imperial College of Science and Technology, London, during Decomber 16-18. Topies under consideration will include: the growth and structure of thin films; thin-film resistors; superconducting thin films; semiconducting thin films; dielectric and insulating thin films; magnetic thin films. Further information can be obtained from the Administration Assistant, Institute of Physics and the Physical Society, 47 Belgrave Square, London, S.W.1.

Erratum. In the communication "The Xg Blood Groups of Negroes" (Gavin, Tippett, Sanger and Race, Nature, 200,$82 ; 1963$ ) the columns following the fifth line of text should be headed:
Male
$\mathrm{Xg}(\mathrm{a}+) \quad \mathrm{Xg}(\mathrm{a}-)$ Female $\mathrm{Xg}(\mathrm{a}+) \quad \mathrm{Xg}(\mathbf{a}-)$ 